\title{
Feasibility of Clove Farming in Gangga District North Lombok Regency
}

\author{
Dewa Kadek Suniantara* \\ Dryland Resource Management Study \\ Program \\ Postgraduate, University of Mataram \\ Mataram, Indonesia \\ suniantara92@gmail.com
}

\author{
I Ketut Budastra \\ Dryland Resource Management Study \\ Program \\ Postgraduate, University of Mataram \\ Mataram, Indonesia
}

\author{
Taslim Sjah \\ Dryland Resource Management Study \\ Program \\ Postgraduate, University of Mataram \\ Mataram, Indonesia
}

\begin{abstract}
The objectives of this study were: (1) to analyze the income of clove farming in Gangga District, North Lombok Regency; and (2) to analyze the feasibility of clove farming in Gangga District, North Lombok Regency. This research used a descriptive method and collected secondary time series data. Data were analyzed using farm income and $\mathrm{R} / \mathrm{C}$ ratio. The study revealed the following: (1) Clove farm income in Gangga District, North Lombok, was IDR. 86,566,875 per seasonal harvest for the last four years since 2015-2019; (2) Clove is feasible to be farmed at time of low clove price with the $R / C$ Ratio of 4.48, 2.47, 3.15, and 1.23, respectively for studied data times. From the $\mathrm{R} / \mathrm{C}$ ratio value, it is seen that clove farming is worthy to do and develop at any time. Thus, this research is expected to be a source of information for those who need it in developing clove farming, especially clove farmers.
\end{abstract}

Keywords- clove farming, clove price, farm income, feasibility

\section{INTRODUCTION}

Lombok is an area that carries out development in the agricultural sector. The agricultural sector is one of the bases that are highly expected in supporting economic growth both at present and in the future $[1,2]$. The target development to achieve is a balanced economy, where the capabilities and strength of the industrial sector are supported by agricultural forces that are able to optimize the use of natural resources, energy, capital, and technology in the physical and social environment which are also able to improve the farmers' welfare [3]. Clove is a native Indonesian plant, widely used as a spicy flavoring in European countries and as the main ingredient in Indonesian cigarettes $[4,5]$. Clove oil is used as aromatherapy and also to treat toothaches [6]. Clove thrives in Madagascar, Tanzania, India, Sri Lanka, and Banda islands in Indonesia where cloves were cultivated [7]. The condition of cloves at the national level has run into ups and downs due to the large price fluctuations and the high costs of harvesting and processing. Meanwhile, on the technical side, clove plants have specific characteristics where the existence of a large harvest is followed by a small harvest in the following year and a major harvest in a certain period. During large harvests or major harvests, the price of cloves tends to decrease which results in farmers losing money so that they do not maintain their plants and caused poor planting and low production [8].

North Lombok Regency is one of the clove-producing areas in West Nusa Tenggara with a fairly large production. Farmers in the dryland areas of North Lombok Regency, especially in Gangga District, cultivate plantation products, which is one of the clove commodities as supporting factors for their family's economy. Clove production in 2018 was 66.90 tons and in 2017 was 44.30 tons [9]. Seeing the high production of clove farming does not guarantee that it can provide high income for farmers as well. The price factor received by farmers plays a very important role in determining the level of business income. The need for planning in doing business is a powerful weapon to achieve the maximum goal, farmers should know the extent to which the feasibility of the business they are doing, by doing simple calculations, so that it can provide decent benefits [10].

North Lombok Regency, especially Gangga District, is an area with a fairly large yield of cloves in West Nusa Tenggara. However, large yields that are not supported by a comparable selling price affected farmers' loss even cutting down the clove trees they own. Moreover, the increasing worker costs are not accompanied by the cloves price. The ideal price of cloves from farmers is IDR $120,000 / \mathrm{kg}$, but in 2018 it was traded in the range of IDR $90,000 / \mathrm{kg}$ for dry cloves [11]. Even this price is also below the range of the cost of production of farmers which is around IDR 100,000 / $\mathrm{kg}$. In July 2019, the price of wet cloves was IDR $21,000 / \mathrm{kg}$ and dry ones IDR 70,000 / kg. In addition, labor costs began to increase since the earthquake that hit North Lombok Regency in August 2018, where labor costs, which initially ranged from IDR 40,000 / day to IDR 50,000 / day, jumped to IDR 70,000 / day to IDR 80,000 / day. The disproportionate price of cloves and labor costs makes farmers confused and many of them leave clove farming by less doing intensive care and mortgaging their clove plants, some even cut down the clove trees, farmers are afraid of taking risk cultivating cloves. Therefore, it is necessary to carry out a feasibility analysis related to the low price of cloves and labor costs which have increased significantly [12].

The latest research related to the feasibility of clove farming when the price of cloves is relatively cheap and labor costs are relatively increase was carried out by Nurhayati [13] under the title "Analysis of the Feasibility of Clove Farming in Kompong Village, Pitumpanua District, Wajo Regency" with the results that show the production of clove farming in Kompong Village, Pitumpanua District, Wajo Regency an average of $323 \mathrm{~kg} / \mathrm{ha}$ and an average income of Rp. 27,068,558 / ha per harvest season and based on the analysis results obtained the value of R/C Ratio 12.02. The value of R/C-Ratio> 1 means that farming in Kompong Village was feasible to develop [13]. The reduction in R/C 
Ratio is significant but still greater than 1 , which means that even though prices and costs fluctuated, clove farming is still feasible to develop.

The purpose of this study was to analyze the income of clove farming and to analyze the feasibility of clove farming in Gangga District, North Lombok Regency. Its role is evident in the country's foreign exchange reserves through exports, providing employment, meeting domestic consumption needs, raw materials for various domestic industries, obtaining added value and competitiveness as well as optimizing sustainable natural resource management. No less than small to large industries which include cigarette, cosmetics, perfume, and spices manufacturing industries that really need clove commodity. Clove (Syzygium aromaticum $L$ ) commodity is one of the plantation commodities that contribute to Indonesia's economy, the plantation sector as an integral part of agriculture has a strategic role in national development [14]. This research is expected to become a source of information for those who need it in developing clove farming, as consideration for decision-makers in developing clove farming, as a reference or source of information for further research on clove farming, and as a reference in doing clove farming for farmers or entrepreneurs in North Lombok Regency.

\section{METHODS}

This research was conducted in October 2020 in Selelos Village, Gangga District North Lombok Regency with the Tumpang Sari Selelos Farmer Group as respondents. The unit of analysis is clove farmers in Selelos Village. The data in this study was a combination of primary data and secondary data. Primary data were obtained from 14 observations and 15 direct interviews with porang farmers as respondents by using a questionnaire and comparing the existing data at the location. The data obtained were clove production data, clove prices, production value, labor costs, and equipment investment from 2015 until 2019. In 2017, no data was obtained due to some of the farmers' cloves did not bear fruit, so the available data was limited and no data were found regarding the 2017 harvest, then the data would be processed using a feasibility analysis and then juxtaposed with available secondary data. Secondary data is data obtained from agencies related to research, especially on the cost and revenue of porang farming.

The data obtained were analyzed using income analysis, which is the difference between total revenue and total expenditure [15], while for the feasibility analysis using the $\mathrm{R} / \mathrm{C}$ ratio analysis that shows the comparison between values of revenue to the value of costs which aims to determine the feasibility of the farming being carried out. Income analysis uses the following formula [15]:

$$
\pi=T R-T C
$$

Information:

$\Pi \quad=$ Revenue (Profit)

$\mathrm{TR}=$ Total revenue

$\mathrm{TC}=$ Total cost

Revenue is obtained from the reduction between total revenue (TR) and total cost. To get total revenue (TR) and total cost (TC) the following formula is used:

$$
\begin{aligned}
& T R=P x Q \\
& T C=F C+V C
\end{aligned}
$$

Information:

$\mathrm{P} \quad=$ Price

Q = Quantity

$\mathrm{FC}=$ Fixed cost

$\mathrm{VC}=$ Variable cost

The feasibility analysis using the $\mathrm{R} / \mathrm{C}$ ratio analysis formula is as follows [15]:

$$
R / C \text { ratio }=\frac{\text { Total } \text { Revenue }}{\text { Total } \cos t}
$$

There are three possibilities obtained from the comparison between Revenue (R) and Cost (C), as follows:

1. R/C-Ratio > 1: farming is feasible to develop

2. $\mathrm{R} / \mathrm{C}-$ Ratio $=1$ : impasses farming

3. R/C-Ratio $<1$ : farming is not feasible to develop

\section{RESULTS AND DISCUSSION}

\section{General description of the area}

North Lombok Regency is located in the northern part of Lombok Island with a position between 80021 '42' South Latitude and 116009 '54' east longitude with the boundaries of the area bordering the north by the Java Sea, in the west bordering the Lombok Strait and West Lombok Regency, in the south, it is bordered by West Lombok Regency and Central Lombok Regency, in the east, it is bordered by East Lombok Regency [9]. North Lombok Regency has a land area of $776.25 \mathrm{Km}^{2}$, and it is administratively divided into five districts, 33 Villages and 371 hamlet, where Bayan District has the largest area with an area of $329.10 \mathrm{Km}^{2}$ and the smallest is Pemenang District with an area of $81.09 \mathrm{Km}^{2}$, the altitude of North Lombok Regency is between 0-3,726 m from the inland sea, the area with an altitude of $0-100 \mathrm{~m}$ from the inland sea reaches $8,095.30$ hectares while $100-500 \mathrm{~m}$ from the inland sea reaches 1,619.06 hectares and above 1000 hectares reaches 539.69 hectares [9].

\section{Characteristics of Respondents}

Age is one of the factors that affect a person's physical ability to carry out activities. The productive age of a farmer tends to be better able to plan and carry out various farming activities. Besides that, age also affects the response of farmers in receiving and determining suitable agricultural technology to be applied. The age range of 15 to 65 years is the range of productive age and considered capable of working and increase income [15]. Based on this age group, the average age of clove farmers is still classified as productive, which means that they are physically and mentally able to produce goods and services. The age group of clove farmers in Selelos Village ranges from 35-55 years and they are considered capable of working, this shows that the clove farming experience that respondent has is very good in farming, the longer the farmer does farming, the better it will be in managing the farming.

\section{Production and Costs of Clove Farming}

From Table 1, it can be seen the clove production from 2015, 2016, 2018, and 2019. There is no data in 2017 because at that time there was no clove harvest. Only a few 
clove trees bear fruit. This is due to the unique characteristics of cloves where there is a large harvest followed by a small harvest in the following year as well as a major harvest in a certain period. It means that in 2017 cloves experienced small harvests even if there were no harvests for some farmers. In 2015, 2016, 2018, and 2019 cloves have a normal harvest even the main harvest.

TABLE I. PRODUCTION AND COST OF CLOVE FARMING IN 2015, 2016, 2018 AND 2019

\begin{tabular}{|l|l|c|l|l|}
\hline Year & $\begin{array}{c}\text { Production } \\
\text { Value }\end{array}$ & Labor & $\begin{array}{c}\text { Investment } \\
\text { Tools }\end{array}$ & Total Cost \\
\hline & Rp/Kg & Rp/person & Rp/harvest & Rp/harvest \\
\hline 2015 & $188,340,000$ & $39,270,000$ & $2,725,000$ & $419,95,000$ \\
\hline 2016 & $90,100,000$ & $33,897,500$ & $2,640,000$ & $365,37,500$ \\
\hline 2018 & $198,000,000$ & $58,520,000$ & $4,320,000$ & $62,840,000$ \\
\hline 2019 & $60,270,000$ & $46,760,000$ & $2,310,000$ & $49,070,000$ \\
\hline
\end{tabular}

The value of clove production is unstable every year. The fluctuation in production value is due to the not optimal clove harvest every year. Usually, clove can be harvested every two years. It can be seen in 2015 where clove harvest increased, however, it decreased in 2016. In 2017 there was no clove harvest due to the absence of fruitful clove plants. The harvest cycle in this clove plant is very unique, although cloves usually bear fruit every year, the amount of production each year is not the same even very unstable. Intensive maintenance of clove plants is needed to support and maintain clove production. Other factors that make clove plants less intensive maintenance are price and cost factors. Low prices of cloves harvest tend to lose farmers losing money so that they do not maintain their plants. This results in poor cropping and low production. The cost factor is also an obstacle advancement of clove farming so that farmers think repeatedly to develop this clove farming.

The labor used in this clove harvest is seasonal. During the clove harvest, the workers will look for work to harvest the cloves. Not many farmers take care of their clove plants so that the results obtained are less than optimal. Only some farmers do the maintenance of cloves so that the results obtained can be optimal. Another reason why farmers are reluctant to carry out maintenance is the relatively high labor costs. The maintenance of this clove plant includes fertilization and land cultivation. There are still a few farmers who do fertilization. In addition, access to obtain fertilizers is limited and if fertilizers are available, only a small amount is available. Cultivation of cloves is very necessary because it can help the process of forming natural nutrients and break the cycle of disease in the soil. However, most farmers do not process the land so that after harvesting, many plant branches die.

\section{Profit and Feasibility Analysis}

$\mathrm{R} / \mathrm{C}$ Ratio is the amount of value that shows the comparison between business revenue $(\mathrm{R})$ and Total Cost (C). It is seen from table 2 where the benefits and value of $\mathrm{R}$ / $\mathrm{C}$ ratio in clove farming. From table 2, it can be seen that the benefits of clove farming are quite good even though the price of cloves is relatively cheap and the labor costs are relatively high. With such a large amount of profit, farmers can meet their daily needs either directly by using or saving stock to run the next farm.

TABLE II. PROFIT AND FEASIBILITY OF CLOVE FARMING IN 2015, 2016, 2018 AND 2019

\begin{tabular}{|l|l|l|l|l|}
\hline \multicolumn{1}{|c|}{ Year } & $\begin{array}{c}\text { Production } \\
\text { Value }\end{array}$ & \multicolumn{1}{|c|}{ Cost } & \multicolumn{1}{|c|}{ Profit } & \multicolumn{1}{|l|}{ R/C } \\
\hline & Rp/ harvest & Rp/harvest & Rp/harvest & \\
\hline 2015 & $188,340,000$ & $41,995,000$ & $146,345,000$ & 4,48 \\
\hline 2016 & $90,100,000$ & $36,537,500$ & $53,562,500$ & 2,47 \\
\hline 2018 & $198,000,000$ & $62,840,000$ & $135,160,000$ & 3,15 \\
\hline 2019 & $60,270,000$ & $49,070,000$ & $11,200,000$ & 1,23 \\
\hline $\begin{array}{l}\text { Rata- } \\
\text { rata }\end{array}$ & $134,177,500$ & $47,610,625$ & $86,566,875$ & 2,83 \\
\hline
\end{tabular}

The value of $\mathrm{R} / \mathrm{C}$ ratio> 1 means that clove farming is still feasible to run even though in 2019 the $\mathrm{R} / \mathrm{C}$ ratio was almost $=1$, which was 1.23 . In other words, the average $\mathrm{R} / \mathrm{C}$ ratio of 2.83> 1 means that for every 100 rupiahs spent, clove farmers earn an income of Rp. 283. Therefore, clove farming from 2015, 2016, 2018, and 2019 is still feasible to be continued and developed. Judging from the development every year the $\mathrm{R} / \mathrm{C}$ ratio has decreased. This is due to a lack of attention regarding the price and labor cost policies that are enforced. Even though there is a policy regarding labor costs that are regulated by village regulations, there are still farmers who destroy the agreed income system. So that, the workforce will move to find a place to work with higher costs. The factors that influence clove farming carried out by Sarmila [16] with the research title Analysis of Factors Affecting the Income of Clove Farmers in Borong Rappoa Village, Kindang District, Bulukumba Regency are as follows:

1. Land area has a significant and positive effect on production.

2. Capital has a positive effect on production.

3. Labor has a negative effect on production.

4. Land area has a significant and positive effect on income.

5. Capital has a significant and positive effect on income.

6. Labor has no significant and negative effect on income

7. Production affects the level of income.

8. Land area affects the level of income through production.

9. Labor affects the level of income through production.

10. Labor has no effect on the level of income through production.

Compared with the analysis results of the factors that influence clove farming in Bulukumba Regency, the factors of land area, capital and labor are factors that influence the increase and decrease of clove production in Selelos Village. Another factor that can be an indicator is the climate that is difficult to predict. Hence, that post-harvest handling of clove farming becomes difficult. On the other hand, whether or climate affects the process of when to fertilize at the right 
time because fertilization is usually done during the rainy season.

\section{CONCLUSION}

Based on the results of research and discussion regarding the feasibility analysis of clove farming in Selelos Village, Gangga District, North Lombok Regency, there are two main conclusions as follows: The production value of clove farming in Selelos Village, Gangga District North Lombok Regency is an average of Rp. 134,177,500 / harvest and an average profit of Rp. 86,566,875 / harvest for all respondents. Based on the results of the analysis, the $\mathrm{R} / \mathrm{C}$ ratio is $4.48,2.47,3.15$, and 1.23 . The $\mathrm{R} / \mathrm{C}$ ratio value of $>1$ indicates that clove farming is feasible to develop.

\section{REFERENCES}

[1] Mubyarto, Pengantar Ilmu Ekonomi Pertanian, Jakarta: Pustaka LP3ES, 2002.

[2] N. Anggoro, Prospek Agribisnis Cengkeh. http://cybex.pertanian.go.id (25/11/2010), 2011.

[3] Runhayat, Aplikasi Ekonomi Institusi dalam Peningkatan Kesejahteraan Petani, Jakarta: Penebar Swadaya, 2011.

[4] K. Putra, "Kelayakan bisnis bertani cengkeh dan durian (studi pada desa silangjana, kecamatan sukasada, kabupaten buleleng", Vol. 4, No. 1, 2014.

[5] A. F. N. Tirsa, M. Wullur \& P. Tumade, "Evaluasi kinerja rantai pasok komoditas cengkeh (studi pada desa lalumpe kabupaten minahasa)", EMBA. Vol. 4, No. 1, pp. 153-164, 2016.
[6] G. D. Arisena, \& K. Mekse, "Struktur dan perilaku pasar komoditas cengkeh di kecamatan busungbiu kabupaten buleleng", J. Ganec Swara. Vol. 3, No. 2, pp. 39-46, 2009.

[7] Aksan, Tanaman Cengkeh (Syzygium aromaticum), http :// www.agribisnis.deptan.go.id/agromedia. Accessed: 28 November 2017, 2008.

[8] A. R. Siregar, "Analisis disparitas harga dan potensi persaingan tidak sehat pada distribusi cengkeh", J. Agribusiness, Vol. 10 No. 3, pp. 3234, 2011.

[9] Badan Pusat Statistik, BPS, Kabupaten Lombok Utara Dalam Angka, Badan Pusat Statistik North Lombok Regency, 2019.

[10] G. Gusnawati, A. Laapo \& D. Howara, "Analisis kelayakan finansial usahatani cengkeh di desa boukecamatan sojol kabupaten donggala provinsi sulawesi tengah", J. Agrotekbis, Vol. 2, No. 3, 2014.

[11] A. Panca. Web.id Harga. Info Terkini Harga Cengkeh Tahun 2020. https://harga.web.id/prediksi-harga-cengkeh-tahun-2016.info Accessed 5 November 2020.

[12] Suliyanto. Studi Kelayakan Bisnis Pendekatan Praktis, Yogyakarta: CV. Andi Offset, 2010

[13] N. Nurhayati, S. R. Busaeri \& I. Hasan, "Analisis kelayakan usahatani cengkeh di desa kompong, kecamatan pitumpanua, kabupaten wajo", J. Wiratani, Vol. 3, No. 1, pp. 47-56, 2020.

[14] W. Muljana, Bercocok Tanam di Cengkeh, Jakarta: Publisher, 2012.

[15] Soekartawi, Analisis Usahatani, Jakarta: UI Press, 2006.

[16] S. Sarmila, Analisis Faktor-Faktor yang Mempengaruhi Pendapatan Petani Cengkeh di Kelurahan Borong Rappoa Kecamatan Kindang Kabupaten Bulukumba, Doctoral dissertation, Universitas Islam Negeri Alauddin Makassar, 2020. 